Open Access

\title{
Different network typologies in patenting activity of academic inventors through time: the case of Italian chemists in the period 2000-2011
}

\author{
Saveria Capellari ${ }^{* *}$ and Domenico De Stefano ${ }^{2}$
}

\footnotetext{
* Correspondence:

saveria.capellari@deams.units.it

'Department of Economics,

Business, Mathematics and Statistics

"B. de Finetti", University of Trieste,

Piazzale Europa 1, 34123 Trieste,

Italy

Full list of author information is

available at the end of the article
}

\begin{abstract}
In this paper, we present the results of a network analysis applied to academic patent data in a subsector of the chemical field in Italy in the period 2000-2011. In particular, we analyse the micro-level interactions to point out the different network structures shaped by university-owned and university-invented patents. We detected three subnetwork typologies (labelled type A, B, and C) that exemplify different qualitative relational structures as well as different attributions to propriety rights. Type A (open science) exemplifies the typical owned patent; type B (multiple ties) represents the hybrid structure with multiple ties and involvement of academics as individuals and of universities as organisation; type C (disconnected subnetworks) represents the typical invented patent with no role of universities as organisation. The whole network seems to show a breaking point in terms of connectivity around 2005, a year that marks a change in policy rule and strategic orientation of Italian universities towards patenting. After 2005, the number of actors grew disproportionally and the network appears disconnected in several comparable components. Also, the composition in terms of subnetwork types changed. The overall picture seems to underline a big structural change dominated by the important increase of academic patenting both direct (university ownership) and indirect (increasing academic patenting).
\end{abstract}

Keywords: Academic patenting, Science-industry linkages, Social network analysis, Co-invention networks, Network components 


\section{Resumen}

En este trabajo se presentan los resultados de un análisis de redes aplicado a los datos de patentes académicas en un subsector del sector químico en Italia en el período 2000-2011. En particular, se analizan las interacciones a nivel micro para precisar las diferentes estructuras de la red que resultan de los diferentes modos de tenencia de patentes originadas en universidades. Ofrecemos una tipología (tipo de etiqueta $A, B, C$ ) que caracteriza diferentes estructuras relacionales, así como diferentes atribuciones de derechos de propiedad. Tipo A (ciencia abierta) es la tenencia típica donde el titular es la universidad; Tipo B (múltiples lazos) es una estructura híbrida con múltiples titulares incluyendo inventores y sus universidades; Tipo C (subredes desconectadas) representa una tenencia típica donde el titular es el inventor universitario. La evidencia muestra un punto de quiebre en la conectividad de la red alrededor de 2005, el año en que cambiaron las regulaciones de patentes y en el que las universidades se re-orientaron hacia la tenencia de patentes. Después de 2005, el número de actores creció de manera desproporcionada y la red parece estar desconectada en varios componentes comparables. También la composición en términos de tipos de subred cambió. El panorama general sugiere cambio estructural grande dominado por el importante aumento de patentes tanto en tenencia directa (propiedad de la universidad) como indirecta (propiedad del inventor).

\section{Résumé}

Dans cet article, nous présentons les résultats d'une analyse de réseau appliquée aux données des brevets universitaires dans un sous-secteur de la chimie en Italie pendant la période 2000-2011. En particulier, nous analysons les interactions au niveau micro pour mettre en exergue les différentes structures du réseau généré par les brevets d'inventions détenus par les universités et par ceux détenus par des propriétaires. Nous avons détecté en particulier trois typologies de sous-réseaux (types A, B et C) qui illustrent différentes structures relationnelles qualitatives ainsi que différentes attributions des droits de propriété. Le type A (science ouverte) illustre le brevet dont l'université est propriétaire; le type B (liens multiples) représente une structure hybride à liens multiples et l'implication des inventeurs et des universités comme personnes physiques et comme personnes morales; le type C (sous-réseaux non connexes) représente le brevet typique d'invention sans aucun rôle des universités comme personnes morales. En termes de connectivité, le réseau entier semble montrer un point de rupture vers 2005, année qui marque un changement dans les règles de la politique et l'orientation stratégique des universités italiennes en matière de brevetage. Après 2005, le nombre d'acteurs s'est accru de façon disproportionnée et le réseau est devenu non connexe dans plusieurs composantes semblables. En outre, la composition en termes de types de sous-réseaux a changé. La présentation générale semble souligner un grand changement structurel dominé par la croissance importante du brevetage universitaire aussi bien direct (propriété de l'université) qu'indirect (propriété de l'inventeur universitaire). 
摘 要

在这篇论文中,我们利用2000-2011年期间在意大利化学领域的一个分支中的学 术专利数据,提出一个网络分析的结果。特别是我们分析了微观层面的互动,指 出由大学拥有和大学发明的专利形成不同的网络结构。尤其是我们检测了三种 子网类型(标记为 A型、B型和C型),表明不同的定性关系结构以及不同的产权归 属。A型(开放科学)体现了典型的(大学)拥有的专利; B型(多关系)表示与多个联 系形成的混合结构,涉及作为个人的学者和作为组织的高校; C型(断开的子网)代 表典型的没有作为组织的大学的作用的发明专利。在2005年左右,整个网络在 连接性方面似乎呈现出一个突破点,这标志着这一年在政策法规方面的变化和 意大利大学朝向申请专利的战略导向。

2005年后,主体的数量并不成比例增长,网络中的几个重要组件出现断开。此 外,在子网类型的组成上也发生了变化。总体情况似乎是强调以学术专利的重 要增长为主导的大的结构变化,包括直接的(大学拥有所有权)和间接的(增加学术 专利)。

\section{Аннотация}

В настоящей статье мы представляем результаты анализа сетей на основании данных по патентованию в академической среде, в частности в химическом секторе, в период с 2000 по 2011 гг.

В частности, мы исследовали взаимодействия на микро-уровне с целью выделения различных сетевых структур применительно к созданным и принадлежащим университетам патентам. Мы обнаружили три типа подсетей (обозначенные типами A, B, C), которые характеризуют различные качественные связи в структурах, равно как и различные отношения в отношении прав собственности. Тип А (открытая наука) представляет собой типичный университетский патент; тип В (многочисленные связи) характеризуется гибридной структурой с многочисленным связями и вовлечением индивидуальных лиц со стороны научных организаций и университетов; тип C (разобщенные подсети) содержат типичные авторские патенты, созданные без участия университетов в качестве координирующей организации. Вся сеть в целом продемонстрировала переломный момент в коммуникациях в 2005 году, когда произошли изменения в законодательстве и стратегической ориентации итальянских университетов в области патентования. После 2005 года число участников стало расти непропорционально, и сеть продемонстрировала тенденцию к расслоению на несколько составляющих. Также, изменился состав компонентов подсетей. Общая картина отражает большое структурное изменение, обусловленное значительным ростом числа академических патентов как в прямом (принадлежность университетам) и непрямом (рост активности академического патентования) аспектах. 


\section{Resumo}

Nesse artigo apresentamos os resultados de uma análise de redes aplicada aos dados de patentes acadêmicas em um subsetor da química na Itália durante o período de 2000 e 2011. Em especial, foram analisadas as interações no nível micro para apontar as diferentes estruturas de redes moldadas pelas patentes de propriedade da universidade e as de propriedade dos inventores. Em particular, foram detectadas três tipologias de subredes (identificada como tipo A, B, C) que exemplificam várias estruturas relacionais qualitativas, bem como diferentes atribuições de direitos de propriedade. O tipo A (ciência aberta, ou open science) exemplifica a típica propriedade de patente; o tipo B (laços múltiplos) representa a estrutura híbrida com laços múltiplos e a participação de acadêmicos como indivíduos e das universidades como organizações; o tipo C (subredes desconetadas) representa a típica patente inventada sem papel das universidades como organizações. Toda a rede parece mostrar um ponto de ruptura em termos de conectividade em torno de 2015, um ano que marca uma mudança na regra de política e orientação estratégica das universidades italianas para a patenteabilidade. Após 2005, o número de atores cresceu desproporcionalmente e a rede apareceu desconectada em vários componentes comparáveis. A imagem geral parece sublinhar uma grande mudança estrutural dominada pelo aumento importante de patenteamento acadêmico tanto direto (propriedade da universidade) e indireto (crescente patenteamento acadêmico).

\section{Multilingual abstract}

Please see Additional file 1 for translation of the abstract into Arabic.

\section{Introduction}

Universities play determinant roles in a knowledge-based society and have wide impacts on the evolution of economies and the collective well-being. Beyond the traditional role of offering higher education-a role that has not lost momentum within contemporary society, with the educational attainment of the population remaining one of the pillars of innovation systems-and performing basic research, universities are now engaged in a set of multifaceted activities pertaining to the third mission. Its general aim is to put in place a variety of strategies to facilitate technology transfer and knowledge exchange with a multiplicity of public and private subjects involved in the process going from basic research to innovation (Etkowitz and Andrew 1998; Florida and Cohen 1999). Among the third mission activities, university patenting is one of the most prominent. University patenting grew rapidly in the USA at the end of the 1980s, and this trend increased all over the world in the ensuing years, in Europe as well as in emerging countries (WIPO 2011). The contribution of academics to the process of invention is not restricted to the direct patent activity of a university. Very often, in particular in Europe and in Italy, and differently from the USA and emerging countries, academic inventors take part to patents assigned to subjects other than universities: private firms, public research organisations (PROs) and other public institutions as well as individual inventors. ${ }^{1}$ If the relative balance between universities and public laboratories depends on the division of labour characterising the National Innovation System, patents assigned to firms are the result of some form of cooperative research between them and the departments, research units, or single researchers belonging to individual universities. 
Inside the flourishing stream of literature (see among others, Balconi and Laboranti 2006; Lissoni 2012) that has tried to understand the reasons and the consequences of this phenomenon, patenting activity of academic researchers has been grouped under the heading of "academic patents" and divided in two typologies: "university-owned patents" (patents having a university as assignee) and "university-invented patents" (having one or more academics as inventors but assigned to other subjects).

The analysis of academic patent data can be particularly interesting because they include information both on individual inventors and on the organisation's ownership, giving interesting insights on the patterns of collaboration between science and industry at the core of the triple-helix mechanism (Leydesdorff and Meyer 2003; 2007). In fact, the crucial role of spurring innovation played by cooperation activities in the process of knowledge creation and diffusion is well grounded in the economic literature, which emphasises, in particular, the relevance of relationships between research institutes and private companies in science-based sectors. These cooperation activities between public and private organisations (hybrid interactions) give rise to networks that are at the core of the process of communication and differentiation between science and market and between public and private control (Leydersdorff and Etzkowitz 1996, 1998). These networks can be also viewed as a loose form of organisation, inside which different actors create real "co-assets" (Powell 1990; Whittington Bunker et al. 2009).

Traditionally, cooperation patterns between academia and industry have been studied by means of Social Network Analysis (SNA). SNA tools allow for the understanding of the structural characteristics that make up the social network of inventors and organisations (each representing a node), showing their importance in the relational mechanisms through several possible statistics, such as centrality or brokerage roles (see among others: Fleming et al. 2007; Uzzi et al. 2007).

Recently, Capellari and De Stefano $(2013,2014)$, in a case study on universityowned and university-invented patents of two Italian universities, identified prototypes of different relational mechanisms of knowledge diffusion through patenting, embedding different rationales for the attribution of property rights. In this paper, we extend that approach to a more general case, focusing on the patenting activities of researchers belonging to a subsector of the Italian academic chemists, namely general and inorganic chemistry.

Our main goal is to study the change occurred in the patterns of collaboration shaped by university-owned and university-invented patents in a period in which the universities came to the forefront as important subjects in patenting activity for the first time. In particular, we will focus on the analysis of micro-level interactions in terms of subnetwork typologies to verify if the relational structure of those coinvention networks changed during the period taken into consideration.

The paper is organised as follows: in the "State of the art" section, we briefly report the recent literature on academic patents; then, in the following section, we describe the adopted methodology; in the "Data and descriptive analysis" section, we illustrate the data set and describe the principal characteristics of the Italian academic patents in chemical scientific sector; in the "Network analysis" section, we present the results of SNA applied to our data; and finally, we draw some conclusions and directions for further research. 


\section{State of the art}

In this section, we briefly mention the two streams of literature at the root of our research work: (i) the role of the academic inventors in patenting and (ii) the SNA methodology to analyse co-invention networks.

The patenting activities of universities were, for a long time, analysed within the framework of knowledge transfer by which the universities were asked to open up towards the real economy, especially bringing basic research into patentable results and eventually giving rise to new companies (typically spinoffs). In this context, the debate was centred on the race to patent, in one respect, and on the discussion of the possible negative feedbacks of patenting on the open science activities of academics, ${ }^{2}$ in another respect. In the race to patent, European universities were found to lag far behind the USA. This result seemed to highlight an inefficiency of European research institutions to transfer scientific discoveries into something immediately useful for the economy (and the society), a consideration that grounded an institutional change of IPR regulation and of a policy push towards universities' direct engagement in patenting. Starting from the early 2000s, it was proved, by an important body of literature (Meyer 2002; Balconi and Laboranti 2006; Crespi et al. 2006; Breschi and Lissoni 2009; Thursby et al. 2009; Geuna and Rossi 2011; Lissoni 2012), that these conclusions were misplaced because they did not take into account the overall patenting activity of academics, excluding those patents not directly owned by universities but in which academic inventors played a key role. Thanks to these studies, the sharp difference between Europe and the USA in the inventions patented was drastically scaled down. The difference was not determined by European academics contributing less to the invention process but, rather, to a different solution to the problem of appropriability. Of course, this fact also changed the possible policy implications. The point was not only to favour the knowledge transfer but also to understand the most favourable way, in terms of patent ownership, to maximise the social welfare.

From an empirical point of view, many attempts have been made to understand whether there are systematic differences between patents owned by universities and those owned by external organisations with respect to the quality of the inventions (Lissoni and Montobbio 2012; Lawson 2013), without reaching so far a definite set of conclusions.

In the recent years, taking into account academic patents (both university-owned and university-invented), several studies focused on the role of academic inventors in the knowledge diffusion process, starting form the idea that innovation, at the firm level, depends on a complex set of factors, among which, the capacity to develop a fruitful relationship with external partners, in particular universities and research organisations (Hagedoorn 2002). Moreover, networks can shape the pattern of knowledge diffusion, conveying tacit knowledge and reducing cognitive as well as organisational distance. In this context, SNA applied to academic patent data appears as the appropriate tool to describe and understand this phenomenon.

In particular, a stream of research was aimed at understanding if the networks arising from academic patents had peculiar characteristics at the global level and which roles academic inventors play inside the network itself. The efficiency of different network structures in knowledge diffusion was tested. In this frame, many efforts were made to detect, in the networks of academic inventors, particular network models or ties generating mechanisms, like small-world model. The small-world model represents a prominent 
mechanism in the network diffusion processes (Fleming et al. 2007; Uzzi et al. 2007; Breschi and Lissoni 2009; Breschi and Catalini 2010), and it is considered particularly suited to maximise the spread of knowledge, because ties are "efficient" and nonredundant. Such a model is typical of the open science environments. Consequently, detecting this kind of structure in networks made up of academics and industrial inventors seems to highlight the predominance of open science relational style in the context of mixed teams. ${ }^{3}$ In addition, SNA has been used in the field of the geography of innovation, particularly for understanding the role of local versus international ties, in shaping innovation activities (for a review, see Autant-Bernard et al. 2007).

The role of individual academic and industrial inventors inside the co-invention networks has also been extensively studied, showing that academic inventors often connect otherwise disconnected actors. These "brokerage roles" (Gould and Fernandez 1989; de Nooy et al 2011) have been adopted to describe the interactions among academic and industrial inventors. Recently, Capellari and De Stefano (2014), adopting an approach combining local and individual relational characteristics, showed that university-owned and university-invented patents could create rather different network structures. They identified three typical subnetworks as prototypes of interaction, defined as: (i) open science, (ii) multiple interactions and (iii) disconnected subnetworks (see Fig. 1).

The first subnetwork (type A, open science, Fig. 1a) is typical of academics collaborating to patents with scientists belonging to other open science organisations. These

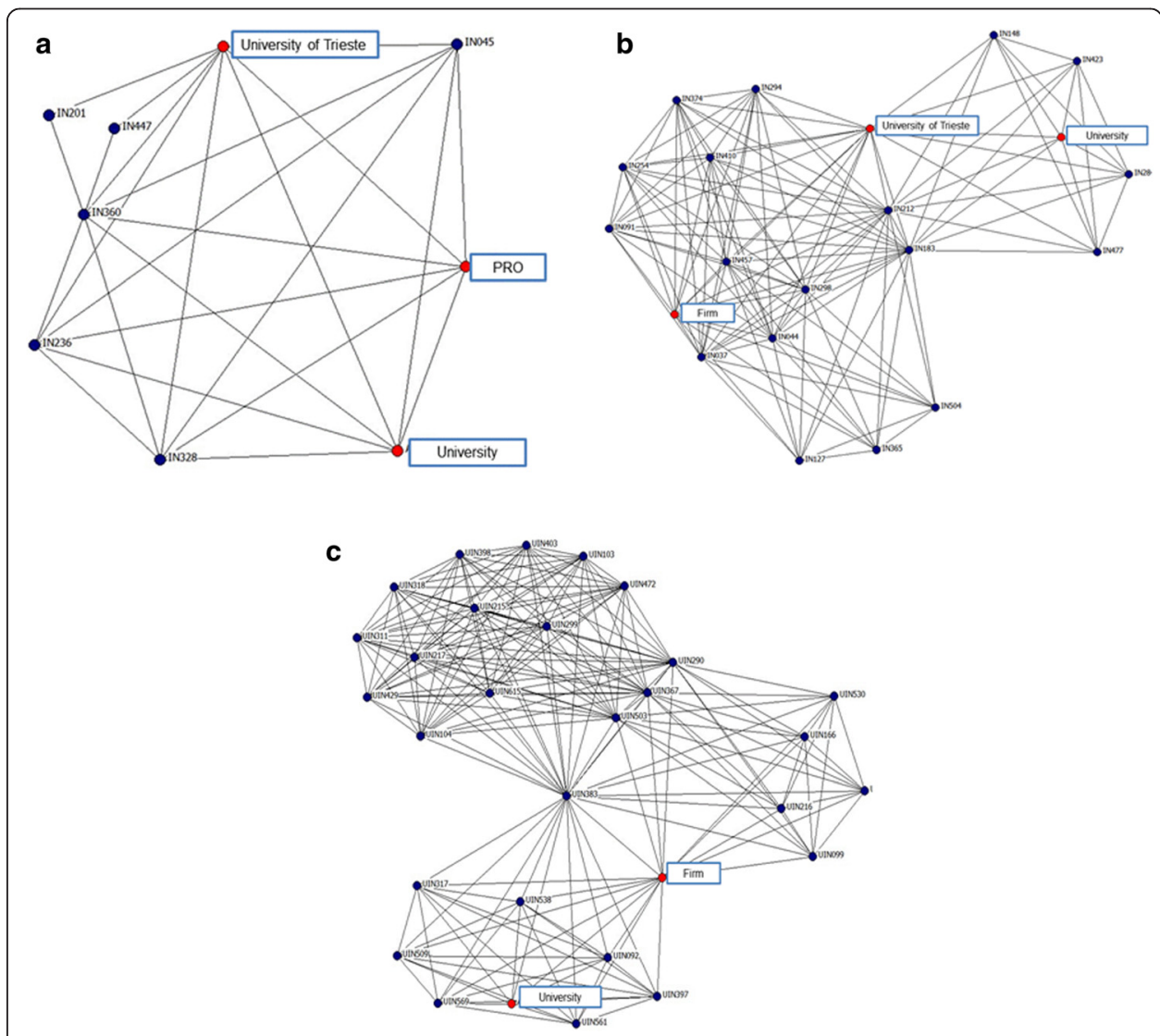

Fig. 1 Subnetwork typologies. Node colours represent assignees (red) and inventors (blue). Source: Capellari and De Stefano (2013). Panel a) type A subnetwork, open science; panel b) type B subnetwork, multiple interactions; panel c) type $\mathrm{C}$ subnetwork, disconnected subnetworks 
structures are composed of homogenous actors and the relational style adopted is very close to that of open science organisation. The patent arises almost directly from research work and the attribution of property rights to the university is straightforward.

The second subnetwork (type B, multiple interactions, Fig. 1b) arises from cooperation of several academic scientists with one (or more) private firm (and industrial inventors), with the university in the role of assignee, at least in one occurrence. In this subnetwork, brokerage and gatekeeping roles of academic are enhanced. Overall, it represents an example of the archetypical hybrid interaction between the two worlds of science and private companies. This subnetwork seems structurally more conducive to a multifaceted knowledge diffusion because of the different channels through which knowledge flows. The attribution of property rights can be more difficult here, and the logic of appropriability can clash with the objective of knowledge diffusion.

The third subnetwork (type C, disconnected subnetworks, Fig. 1c) emerges from inventions owned by private firms to which individual academics participate as inventors and without any involvement of the university as organisation. In this subnetwork, academics play the role of brokers, connecting several non-academic co-inventors. Patents often arise as the result of the consultancy work of academics. In the general case, the research work is carried out mainly with the resources made available by the private firm that retains the property rights of the invention.

The three above described typologies, highlighting the possible links between appropriability and the network structure, seem to be well suited to connect the changes on the ownership attribution with the patterns of the diffusion of knowledge that is the focal point of our analysis.

\section{Methodology}

To study the co-invention network created by an Italian academic inventor in the chemistry science sector, we follow the approach of Capellari and De Stefano (2013, 2014). In particular, we include inventors and assignees in the network, even if they belong to different "levels" of analysis, accounting for both the ownership and the individual levels embedded in each patent. ${ }^{4}$ In this way, we introduce, in the analysis, the information on relationships among inventors and between inventors and organisations (as assignees). Consequently, in such a network, we can identify different types of links that may convey different degrees of knowledge transfer-from patenting activity-between actors: (i) co-invention: inventor-inventor link (I); (ii) co-assignment: assignee-assignee link $^{5}$ (A); and (iii) observed cross-level link: inventor-assignee link. In particular, we suppose that, according to the nature of the actors involved in the relation, different degrees of knowledge may be transferred via patents.

Co-invention relations are the typical collaboration ties among inventors and are the most important knowledge exchange mechanism among intra-level actors (at the individual level). Co-assignee relations can typically be considered an intra-level relationship (at the ownership/organisation level) and may convey scarce knowledge transfer, being mainly an inter-organisational agreement. The observed cross-level link represented by the inventor-assignee link can be, on the contrary, an important channel of knowledge exchange and spill-over effects mediated by the collaboration for patent. This importance is due to the different modes of functioning of the two main organisations involved in academic patenting activities, namely universities and private firms. 
Universities, belonging to the open science environment, are less hierarchically organised, and academic scientists can often get in contact with different hierarchical levels of the external organisations (industrial inventors as well as management) to directly convey their (research-based) knowledge through different channels. Therefore, crosslevel relationships are tangible and their effects on knowledge diffusion processes should not be neglected. Our main assumption is that cross-level relationships are one of the core channels of patent-based knowledge transfer.

The methodology we adopt to disentangle these types of relations is based on certain SNA tools, such as the counting of network substructures and brokerage analysis. In particular, we analyse interactions by exploring the subnetwork structures in both university-owned and university-invented patents, adopting a clustering approach, and applying a blockmodeling technique (Doreian et al. 2004) to identify clusters of regular equivalent inventors/assignees. This will lead us to "qualitatively" classify subnetworks into one of the three types (type A, type B or type C) defined in Capellari and De Stefano (2014). After this step, also, an in-depth analysis of the detected subnetwork typologies is performed. In particular, following Gould and Fernandez (1989), we check the role of each individual brokerage role covered by the actors according to the classification of inventors based on their affiliation. In detail, four brokerage roles are considered: coordination, broker, gatekeeper and liaison. The first two involve mediation among members of a given group. If the mediator is a member of the group, he or she is regarded as a coordinator. If the mediator comes from outside of the group, he or she is defined as the broker. The other two brokerage roles describe mediation among members of different groups. The mediator is a gatekeeper when she or he channels the knowledge flow from the outside to his group; the mediator is a liaison when he or she mediates among members of different groups without belonging to these groups himself/herself.

\section{Data and descriptive analysis}

In the present paper, we used the APE-INV database and related information (Lissoni et al. 2008, 2013) in order to collect patents authored by Italian academic inventors in chemistry. Firstly, we isolated the academic inventors belonging to the scientific field (CHEM 03, general and inorganic chemistry ${ }^{6}$ ) recorded as inventors in the APE-INV database, in the period from 2000 to 2011. The data also provided the applicant's names. Then, from Espacenet, ${ }^{7}$ we retrieved the names of all of the non-academic inventors registered in each patent. For each inventor, we tried to determine the affiliation by looking at different sources of data, in particular, professional social networks (essentially, academia.edu, LinkedIn, Patent Buddy). The inventor was, then, associated with a particular organisation if the occurrence of the patent was accompanied by other information on professional activities and affiliations of the inventor. The web search made it possible to identify the majority of non-academic inventors. The non-academic inventors were classified according to their affiliation: industrial inventors, PRO inventors, and students/post-doc/technicians within universities. Assignees were classified in three categories: universities, PROs (for all the public research organisations different from universities) and private firms. For each category, we considered whether the geographical localisation was in Italy (headquarters located in Italy) or outside the national borders (headquarters located outside Italy). For every assignee, we 
identified the relevant industry and considered whether the company was ranked among the top $2000 \mathrm{R} \& \mathrm{D}$ world investors, according to the European R\&D scoreboard (European Commission 2014).

The resulting dataset is composed of 167 academic patents (only six are assigned to inventors only), and 20 are owned by one of the Italian universities (excluding coassignment). The remaining patents are derived from the collaboration of at least one academic inventor to patents owned by external organisations or in co-assignment. The great majority of patents published in the period 2000-2011 are assigned to companies with an important role of PROs before 2005. Co-patenting seems to be an important phenomenon. In fact, patents co-owned by universities and other organisations are as many as university-owned patents.

The total number of academic inventors is $361: 70 \%$ of them are affiliated to the science sector CHEM 03 and $30 \%$ belong to other sectors (other chemical sectors, biology and medical science, industrial engineering). Only a limited number of academics are recorded as multiple inventors; the vast majority signed only one patent in the whole period.

When looking at the characteristics of private companies, the prevailing sectors are, as expected, the chemical, pharmaceutical and energy industries (oil, gas electricity generation and renewable energies), with other sectors close behind (e.g. metallurgy and concrete industries). Several private companies involved are among the leading organisations in the world. In fact, $20 \%$ of them are among the 2000 firms ranked in the R\&D Scoreboard (European Commission 2014). Moreover, looking at the qualitative information available, we can say that a strategy of open innovation is intentionally followed by many organisations, with cooperation with universities and PROs being a structural characteristic of their behaviour.

The distribution of patents among the IPC (International Patent Class) mirrors the characteristics of assignees and inventors covering a wide spectrum of sectors. In particular, $75 \%$ of the patents are included in the following four sectors: medical science, organic chemistry, organic macromolecular compounds and physical or chemical processes. The large percentage of patents in organic chemistry may be surprising but is explained by the fact that CHEM 03 covers inorganic chemistry as well as general chemistry. Moreover, as mentioned before, academic patents show many collaboration ties of CHEM 03 scientists to other science sectors (see above).

After a preliminary analysis, we split the data into two periods: from 2000 to 2005 (period 1) and from 2006 to 2011 (period 2) mainly because of two reasons. The first one is related to patenting activity of Italian universities which started to increase in the first half of 2000 but took off after 2005. In fact, in our data, $80 \%$ of the owned patents (only universities as assignees) were issued after 2005. Second, during the years from 2000 to 2005, significant changes in the IPR Law were implemented. The IPR Law was first changed in $2001^{8}$ introducing the "professor privilege," moving in an opposite direction with respect to the other European countries that in the same years decide to cancel it. The 2001 law found the strong opposition of many Italian universities and raised a heated debate that led to a new change. In 2005, the Industrial Property Code (IPC), approved with Legislative decree 30/2005, reintroduced the right for the universities, as employers, to retain the ownership over the inventions created by their academics "when stemming from research either privately financed or funded by public research institutions different to the one to which the inventor belongs" (Art 65. Pr.5), ${ }^{9}$ 
thus encompassing the vast majority of academic inventions. Moreover and perhaps more importantly, during the first half of the 2000s (and notwithstanding the 2001 Law), many Italian universities issued patent regulations and set their Technology Transfer Offices (Baldini et al. 2014). After 2005, we can say that the rules on property rights attribution were sufficiently stable at national as well as at local level. This partition in two time frames is also confirmed by the network analysis. In fact, looking at the evolution over the two periods, a breaking point in terms of connectivity is observed. After 2005, the number of actors increased (from 251 to 367), the average degree also became greater and new assignees appeared. Patent distribution over the two periods, briefly summarised in Table 1 , shows clear evidence of an important quantitative change: in the second period, the number of patents showed a $20 \%$ increase but the number of academic inventors more than doubled.

These two periods seem to embed a rather different way of patent production. However, in both periods, as will be clearer in the network analysis, patents were the result of important cooperation activities between open science and private organisations, likely assuming different shapes due to different strategies of universities and companies.

\section{Network analysis}

In this section, we present the results of the network analysis distinguishing the two time frames (2000-2005, 2006-2011) previously identified.

The overall network is made up of 545 actors (96 assignees and 449 inventors) and 167 patents. Inventors come mostly from universities (56.6 \%) and private firms (37.4\%). Only a few inventors come from research organisations (6.0\%), although PROs are prominent assignees in the network, at least in the first period. The overall network characteristics, reported in Table 2, match those found in previous studies. The network density is low (0.014), the degree centralisation (along with other types of centralisation) is negligible and the average degree is high.

The network in the first period (Fig. 2a) is quite disconnected (the number of components is 26). However, the network shape is mainly governed by two relatively important components built up around two prominent public assignees. The first large component is shaped around a large public research organisation, the CNR (Italian National Research Council), and contains approximately one third of the total actors active in this period. The CNR role is highlighted by the value of the centralisation index, which is significantly higher (14.3\%) with respect to the one detected in both the overall networks and the period 2 network (both around $6 \%$ ). Furthermore, the CNR links, through co-patenting, half of the universities already present in the

Table 1 Distribution of patents (by ownership)

\begin{tabular}{lll}
\hline & Period & \\
\cline { 2 - 3 } & $2000-2005$ & $2006-2011$ \\
\hline Academic patents (total) & 73 & 94 \\
Owned by & & 14 \\
University & 6 & 65 \\
Firm or PROs & 52 & 9 \\
Co-assigned & 15 & \\
\hline
\end{tabular}

${ }^{\mathrm{a}}$ The six patents where assignees are only inventors are not counted 
Table 2 Statistics for the overall and the two subperiod networks: 2000-2005 (period 1) and 2006-2011 (period 2)

\begin{tabular}{|c|c|c|c|}
\hline & \multicolumn{3}{|l|}{ Statistics } \\
\hline & Overall & Period 1 & Period 2 \\
\hline Nodes & 545 & 251 & 367 \\
\hline Of which assignee (firms, PROs, universities) & 96 & 52 & 60 \\
\hline Density & 0.014 & 0.026 & 0.020 \\
\hline \# Link & 148240 & 31365 & 67161 \\
\hline \# of components & 27 & 26 & 31 \\
\hline \# of nodes in giant component (\% nodes) & $276(50.6 \%)$ & $38(15.2 \%)$ & $51(13.9 \%)$ \\
\hline Average degree & 15.4 & 13.3 & 15.0 \\
\hline Network centralisation & $6.3 \%$ & $14.3 \%$ & $6.2 \%$ \\
\hline
\end{tabular}

network. Its prominence is not surprising because, similar to the French experience, in the Italian innovation system-until the recent changes-the universities were especially devoted to basic research activities, whereas the CNR function was related to more applied research (Lawton-Smith 2006). Moreover, as noted by Lissoni et al. (2013), in countries with a public research system dominated by large public laboratories and governmental agencies (such as France and Italy), the latter used to retain control over the IPRs on the academic research they funded. According to our classification, the CNR component can be classified mainly as a subnetwork of type A because it is developed in an open science environment. In only one occurrence, the CNR co-patent with a private firm. In all the other cases, the CNR patents are in coassignment with several universities (Bologna, Milano, Rome and others): five out of the twelve universities that were assignees in this first period. The CNR seems then to act as a coordinator for patenting activity of the public research sector, probably having the role of financing particular streams of research. The second component of this period is almost as large as the CNR one and performs a similar role, although here, the coordination is aimed directly towards the researchers (universities as organisations seem to have no role). This component is build up around a Consortium of Italian universities (none of them appearing as assignee), international universities, multinational private firms and foreign academic inventors. This is a complex instance of a type B subnetwork, where academic inventors and researchers from private companies collaborate with each other in taking out patents in which universities and firms are co-assignees.

Besides these large structures, most of the other components of the first period are relatively small but not less interesting, being often composed of a mix of academic and industrial inventors collaborating on patents owned by private companies. In particular, few academics work with a variable number of non-academic inventors. These components represent instances of disconnected subnetworks related to university-invented patents (type $C$ in our classification system), and looking at the number of these components, they can be considered the distinguishing characteristic of the relational structure in the first period: there are 20 type $C$ subnetworks. It is worth mentioning that one of these structures is rather complex, being formed by the interactions of one assignee and an academic inventor (from Torino University) acting as a broker connecting other academics (from his own university and external 


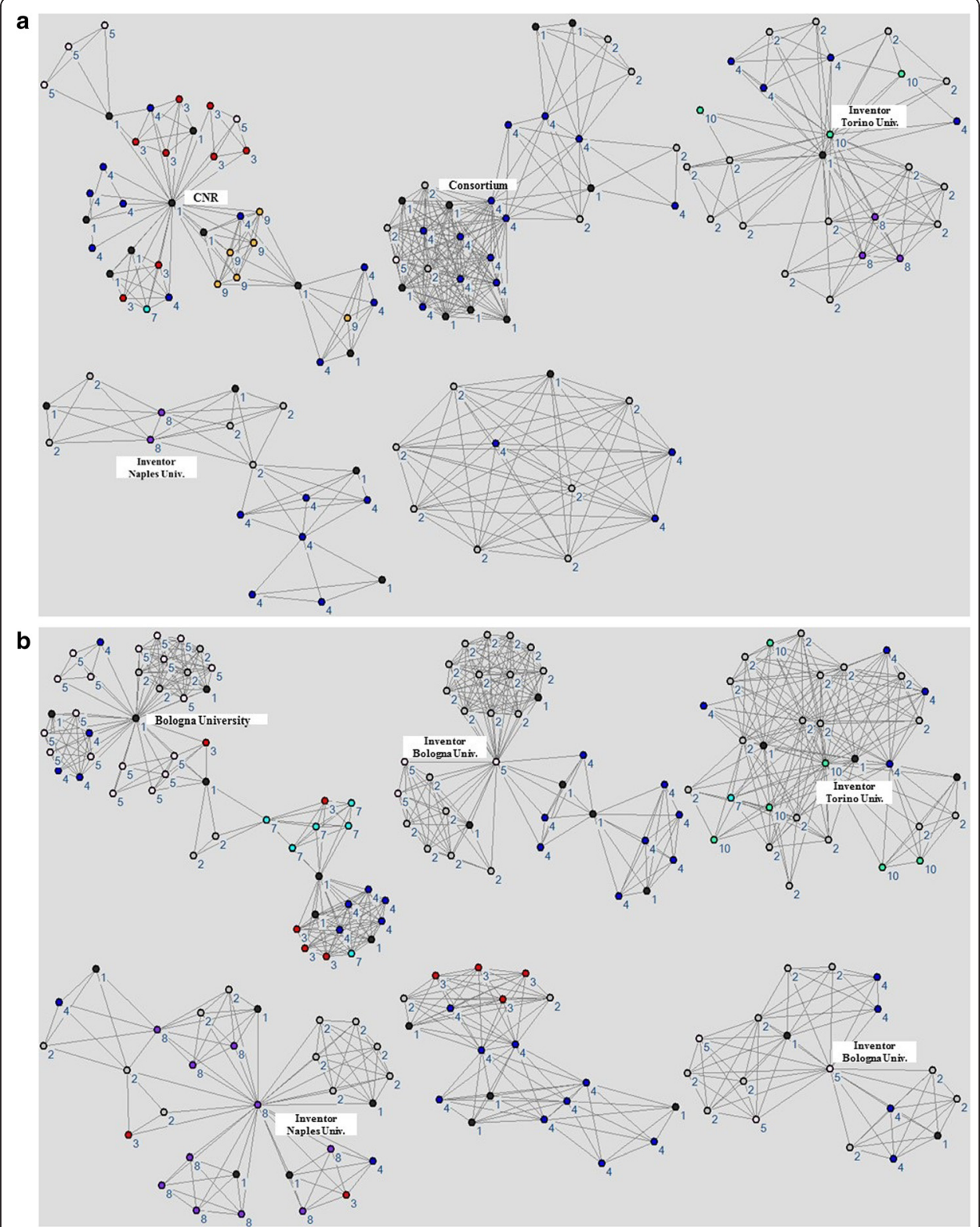

Fig. 2 Principal network components. a Period 1 network. b Period 2 network. Node colours and labels represent node type: (1) assignees (black); (2) inventors from private firms (grey); (3) inventors from research centres (red); (4) academic inventors (blue); (5) academic inventors from Bologna University (pink); (7) academic inventors from Milano University (light blue); (8) academic inventors from Naples University (purple); (9) academic inventors from Roma La Sapienza University (orange); (10) academic inventors from Torino University (light green)

universities) and industrial inventors. This is a subnetwork that will maintain its importance also in the subsequent period.

In the second period (Fig. 2b), the connective role of the CNR ceased and the network seemed to become more disconnected (31 components). However, many components are now more complex, generally flourishing around universities and private companies. Briefly, this period is characterised by the lack of a strong centre, connecting most inventors and assignees. The presence of universities as assignees became clearly more important while the disconnected subnetworks around one or two private 
companies lost momentum. We note an increasing number of type A subnetworks centred around universities (no more PROs). Also, we note a non-negligible presence of universities involved in co-assignments. The largest component is shaped around the University of Bologna, which seems to cover the role CNR had in the previous period (even if on a smaller scale). University of Bologna gives rise to an interesting type B subnetwork, and moreover, several (4) type C subnetworks are generated by Bologna academics (collaborating with pharmaceutical companies located in the same region). The type B subnetwork is generated by owned-patents in co-assignment with two different universities and a PRO and by cooperative activity with a university spin-off together with a role of gatekeeping of some academic inventors. However, the overlap between owned and invented networks is quite low.

On the opposite side, the number of type $C$ subnetworks has been reduced to 14, but their complexity is increased in several respects. With complexity here, we refer to the tendency of actors, particularly individual inventors, in being involved in many patents with the presence of several different assignees and involving different groups of, otherwise disconnected, inventors. As a consequence, in this period, we expect the brokerage role, in connecting different realms (mainly university-industry), of individual inventors to be enhanced with respect to the previous period. In fact, a relevant connecting role of some inventors emerged and several other academics, already present in the first period, become more central.

In this period, academic inventors covered all brokerage roles, especially those of gatekeepers, brokers and liaisons in all three types of subnetworks. These academic inventors were mainly full professors in inorganic chemistry working at universities located in northern Italy and with long scientific careers. In addition, some industrial inventors also played strategic roles, acting as gatekeepers (connecting realms of industry and academia). Differently from other studies, here, the brokerage roles of academic inventors are enhanced only within small disconnected components and especially in type $\mathrm{C}$ subnetworks. One complex structure of this kind is an evolution of a previous existing component (see Fig. 2b) where an academic inventor (from Torino University) signed many patents with a private company as assignee, connecting industrial as well as other academic inventors. We do not observe any link with the university of affiliation as organisation; however, we can detect an important array of connections between the prominent inventor and other academic inventors belonging to different Italian universities.

To understand better the change which occurred in the second period, we performed an exercise considering the compositional change of the network, that is detecting the number and the quality of the actors present in the first period but not in the second. In this way, we can isolate the change occurred through time as well as the persistence of nodes in the two periods. We note that only 14 out of the 52 assignees persist after 2005 (about 1 out of 4), and consequently, 46 out of the 60 assignees in the second period are brand new organisations involved in the patenting activities of the academic inventors. It is worth noting that 10 out of the 17 universities of the second period were not present before 2005. Regarding the inventors, only 47 out of 199 (about 24\%) persisted in the second period from the previous one. It is worth noting that both the case described before which are the result of a positive evolution of subnetworks are already present in the first period. 
The overall picture seems to capture the big change occurred in this time frame, that is a sharp increase in university patenting both directly (ownership) and indirectly (major role of academic inventors). The reasons for this are of course many, but we can say that the policy change oriented towards universities' third mission has played an important role.

We can observe a compositional change between the two periods with many individual universities becoming, for the first time, active in the field. In the meantime, we observe a decrease in small disconnected subnetworks; however, we cannot say, with the available data, that there has been a definite substitution effect between the two kinds of subnetworks.

A common characteristic over the two periods is that the university-industry knowledge diffusion seems to be suffering from different limitation effects. In period 1, this limitation was due to the large concentration of the patents' property around assignees that stopped their activities in recent years (at least in this field). In the second period, the limitation was due to the emergence of several disconnected components that likely mirrored the scientific competences of the academic inventors within their own research groups and universities. However, the university and the academic inventors give rise to more interesting structures at least in terms of increasing the number of published patents as well as the knowledge diffusion processes, thanks to the rather complex structures that appear to be formed or in formation around prominent inventors and universities.

\section{Conclusions and directions for further research}

In this paper, we described the co-invention networks generated by university-owned and university-invented patents signed by Italian academic chemists during the period between 2000 and 2011 by means of SNA.

The study analysed micro-level interactions by exploring the subnetwork structures in owned and invented patents verifying if the typologies identified in previous studies-open science (type A), multiple interactions (type B) and disconnected subnetworks (type C)-were a good instrument to understand the change occurred in the network of collaboration in the mentioned period. These typologies represent different relational styles as well as different solution to the appropriablity problem. From this second point of view, the type A claims for a university ownership whereas type $\mathrm{C}$ claims for a company's ownership. The type B subnetworks represent the most complex case (multiple ties linking organisations as well as industrial and academic inventors) where the attribution of property right could be more uncertain. The results confirmed that the three previously mentioned subnetwork typologies could be identified in particular regions of the network structure.

We performed a distinct analysis of the two time frames (2000-2005, 2006-2011). After 2005, the number of actors increased and new assignees appeared. This change follows a greater engagement of Italian universities in patenting activity stimulated by important policy changes.

Comparing the occurrence and the nature of the three subnetwork typologies, we verify in the second period an increase in the type A (open science) subnetwork and a parallel decrease in the type $\mathrm{C}$ (disconnected subnetworks). It seems that, between the two periods, an organisational change occurred inside the public sector, with the 
reduction of the coordination role of PROs in favour of a major role of the individual universities.

The hybrid structures, mainly represented by the type B, are more frequent in the second period. The role played by academic inventors in collaboration with the private sector becomes in several cases more complex, showing an increase of degree of connectivity with academics belonging to different universities.

The overall picture seems to underline a big structural change dominated by the important increase of university patenting. Substitution effects between different forms of ownership could have been possible but they cannot be properly measured with the instruments at hand. In this respect, the analysis cannot be conclusive but opens the way to further research developments. The first step of the future research will be the launch of a survey on the most prominent actors of the described subnetworks. The survey will be devoted to investigate some central questions, such as those concerning the efficiency of network representation described in this study, the effectiveness of the cooperation with respect to the patent's value and the possible disputes on the appropriability rules. On this basis, we will be able to better understand the relationship between the structure of the network and the exogenous factors guiding individual and institutional choices.

\section{Endnotes}

${ }^{1}$ In Italy, the number of individual inventors recorded also as assignees is really limited.

${ }^{2}$ We cannot focus here on this point because it would bring us far away from our focus. However, it is worth mentioning here that the prevailing evidence on this point favours the idea of a complementarity between high-level research and patenting (see among others, Meyer et al 2005, Azoulay et al. 2009). For a theoretical approach to the allocation of propriety rights to University see Aghion and Tirole 1994 and Verspagen 2006.

${ }^{3}$ The point is far from being trivial, given the fact that these teams are crossing the boundaries of different organisations: the firm, focused on appropriability problems, and universities, focused on knowledge diffusion (or, at appropriability through diffusion).

${ }^{4} \mathrm{We}$ are aware that we are dealing with multilevel data since we deal with two level of analysis: the individual level (inventors) and the organisation level (assignees). Furthermore, inventors are possibly nested into assignees (since they can be employers or researchers hired by that organisation). However, we allow nodes belonging to different level of analysis to be placed on the same network because in this way, we can observe different kinds of university-industry interactions, even those mediated by assignees.

${ }^{5}$ This link can also represent an inventor-inventor link (or inventor-assignee link) whenever the individual inventor is registered as the assignee of the patent. In the following information, we disregard this possible complication because we assume the inventor co-assignment relationship between inventors is "absorbed" by the co-invention link.

${ }^{6} \mathrm{CHEM} 03$ is the code for General and Inorganic Chemistry used by the Italian university official classification of scientific disciplines. The choice to limit the analysis to this scientific sector is related to data availability and reliability.

${ }^{7}$ Espacenet is the EPO engine to search for patent applications (http://www.epo.org/ searching-for-patents/technical/espacenet.html).

${ }^{8}$ Before 2001, the IPR Law, dating back to the 1939 (Royal Decree n.1127/1939), stated that IPRs on employees' inventions were granted to the employer, when the 
invention stemmed from research carried out during the accomplishment of the employees' duties or during a contract (Baldini et al. 2014). The rule was per se conducive to university patenting, but the Italian university system was very centralised, and universities lacked the necessary autonomy to move in that direction until the mid 1990s.

${ }^{9}$ The Code was certainly the result of a compromise between different positions. In fact, the 65 articles, Par. 1, attribute "to the researchers employed in public research institutions (i.e. universities and PROs) the exclusive propriety right over their inventions"(professor privilege), but the Par. 5 lifts the "professor privilege" in case of inventions stemming from research at least partially privately financed or from a specific research project that was, at least partially, financed by a public institution different from that of affiliation of the inventor.

\section{Additional file}

Additional file 1: Translation of the abstract into Arabic. (PDF $132 \mathrm{~kb}$ )

\section{Competing interests}

The authors declare that they have no competing interests.

\section{Authors' contributions}

Both authors conceived the study and participated in its design. SC performed the survey of previous literature to set the research question. DDS performed the network analysis. Both authors discussed the results and wrote jointly the manuscript. Both authors read and approved the final manuscript.

\section{Acknowledgements}

We are grateful to the anonymous referees for their useful comments and suggestions. Special thanks are due to Francesco Lissoni (GREThA — Université de Bordeaux) for having made available the APE-INV database on academic inventors and to Gianni Perini (University of Trieste) for his valuable contribution to the building of the complete dataset used in the analysis.

\section{Author details}

'Department of Economics, Business, Mathematics and Statistics "B. de Finetti", University of Trieste, Piazzale Europa 1, 34123 Trieste, Italy. ${ }^{2}$ Department of Political and Social Sciences, University of Trieste, Piazzale Europa 1, 34123 Trieste, Italy.

Received: 8 July 2015 Accepted: 31 March 2016

Published online: 21 April 2016

\section{References}

Aghion P, Tirole J (1994) The management of innovation. Q J Econ 109:1185-1209

Autant-Bernard C, Mairesse J, Massard N (2007) Spatial knowledge diffusion through collaborative networks. Pap Reg Sci 86:341-350

Azoulay P, Ding W, Stuart T (2009) The impact of academic patenting on the rate, quality and direction of (public) research output. J Ind Econ 57:637-676

Balconi M, Laboranti L (2006) University-industry interactions in applied research: the case of microelectronics. Res Policy 35:1616-1630

Baldini N, Fini R, Grimaldi R, Sobrero M (2014) Organisational Change and the Institutionalisation of University Patenting Activity in Italy. Minerva 52:27-53.

Breschi M, Catalini C (2010) Tracing the links between science and technology: an exploratory analysis of scientists' and inventors' networks. Res Policy 39:14-26

Breschi S, Lissoni F (2009) Mobility of skilled workers and co-invention networks: an anatomy of localized knowledge flows. J Econ Geogr. 9:439-468

Capellari S, De Stefano D (2013) Academic inventors and patenting activities: a case study on university-owned and university-invented patents in two Italian universities. Working paper Big Innovation Center. Lancaster University, UK

Capellari S, De Stefano D (2014) University-owned and University-invented patents: a network analysis on two Italian universities. Scientometrics 99:313-329.

Crespi G, Geuna A, Verspagen B (2006) University IPRs and knowledge transfer. Is the IPR ownership model more efficient? SPRU Electronic Working Paper Series 154.

de Nooy W, Mrvar A, Batagelj V (2011) Exploratory social network analysis with Pajek. New York: Cambridge University Press

Doreian P, Batagelj V, and Ferligoj A (2004) Generalized blockmodeling. New York: Cambridge University Press

Etzkowitz H, Andrew W (1998) Entrepreneurial science: the second academic revolution. In: Etkowitz H, Webster A, Healey P (eds) Capitalizing Knowledge: New Intersections in Industry and Academia. SUNY Press, New York

European Commission (2014) The 2013 EU Industrial R\&D Investment Scoreboard., Bruxelles

Fleming L, King C, Juda Al (2007) Small worlds and regional innovation. Organ Sci 18:938-954 
Florida R, Cohen WM (1999) Engine or infrastructure? The university role in economic development. In: Branscomb LM, Kodama F, Florida R (eds) Industrialising knowledge. University-industry linkages in Japan and the United States. MIT, Cambridge, pp 589-610

Geuna A, Rossi F (2011) Changes to university IPR regulations in Europe and the impact on academic patenting. Res Policy 40:1068-1076

Gould RV, Fernandez RM (1989) Structures of mediation: a formal approach to brokerage in transaction networks. Sociol Methodol 19:89-126

Lawson C (2013) Academic inventions outside the university: investigating patent ownership in the UK. Ind Innov 20:385-398 Lawton-Smith H (2006) Universities, innovation and the economy. Routledge, London

Leydesdorff L, Meyer M (2003) The triple helix of university-industry-government relations. Scientometrics 58:191-203

Leydesdorff L, Meyer M (2007) The scientometrics of a triple helix of university-industry-government relations. Scientometrics 70:207-222

Lissoni F (2012) Academic patenting in Europe: an overview of recent research and new perspectives. World Patent Inf 34:197-205

Lissoni F, Montobbio F (2012) The ownership of academic patents and their impact. University of Turin, Evidence from five European countries. Working paper

Lissoni F, Llerena P, McKelvey M, Sanditov B (2008) Academic patenting in Europe: new evidence from the KEINS database. Res Eval 17(2):87-102

Lissoni F, Pezzoni M, Poti` B, Romagnosi S (2013) University autonomy, the professor privilege and academic patenting: Italy, 1996-2007. Ind Innov 20(5):399-421

Meyer M (2002) Tracing knowledge flows in innovation systems. Scientometrics 54:193-212

Meyer M, Du Plessis M, Tukeva T, Utecht J (2005) Inventive output of academic research: a comparison of two science systems. Scientometrics 63:145-161

Powell W. W (1990) Neither market nor hierarchy: Network forms of organization. Research in Organizational Behavior 12: $295-3$

Thursby J, Fuller A, Thursby M (2009) US faculty patenting: inside and outside the university. Res Policy 38:14-25

Uzzi B, Amaral LN, Reed-Tsochas F (2007) Small-world networks and management science research: a review. Eur Manag Rev 4:77-91

Verspagen B (2006) University research, intellectual property rights and European innovation systems. J Econ Surv 20:607-632

Wipo (2011) The changing face of innovation. World Intellectual Property Report, Geneva

Whittington, K B, Owen-Smith J, Powell W W ( 2009) Networks, Propinquity and Innovation in Technological

Communities Administrative Science Quarterly. 54:90-122

\section{Submit your manuscript to a SpringerOpen ${ }^{\circ}$ journal and benefit from:}

- Convenient online submission

Rigorous peer review

- Immediate publication on acceptance

- Open access: articles freely available online

- High visibility within the field

- Retaining the copyright to your article

Submit your next manuscript at $\boldsymbol{~ s p r i n g e r o p e n . c o m ~}$ 